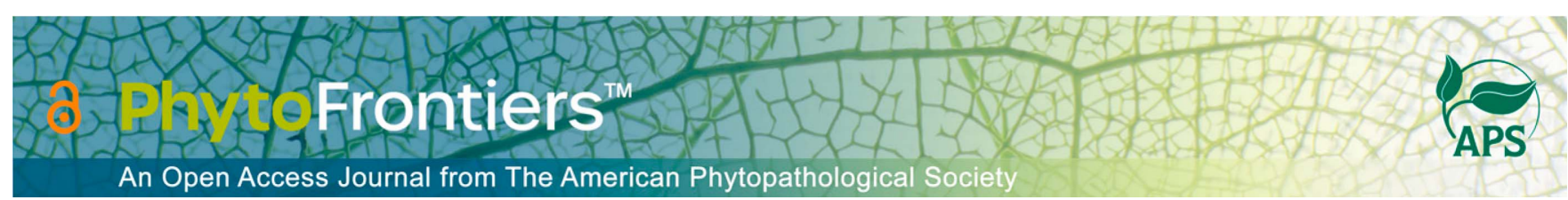

\title{
Research
}

\section{Bacillus subtilis GB519 Promotes Rice Growth and Reduces the Damages Caused by Rice Blast Fungus Magnaporthe oryzae}

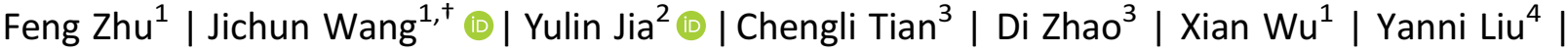 \\ Dongyuan Wang ${ }^{5} \mid$ Shanyan $\mathrm{Qi}^{5} \mid$ Xiaomei $\mathrm{Liu}^{1}\left|\mathrm{Li} \mathrm{Li}^{1}\right|$ Zhaoyuan Jiang ${ }^{1}$ | Yushi $\mathrm{Li}^{6}$ |
}

1 Institute of Plant Protection, Jilin Academy of Agricultural Sciences, Changchun 130033, China

2 United States Department of

Agriculture-Agricultural Research Service Dale Bumpers National Rice Research Center, Stuttgart, AR 72160 , U.S.A.

${ }^{3}$ Analytical Instrumentation Center, Shenyang Agricultural University, Shenyang 110161, China

${ }^{4}$ Vegetable and flower Science Research Institute of Jilin Province, Changchun 130031, China

${ }^{5}$ College of Plant Protection, Jilin Agricultural University, Changchun 130118, China

${ }^{6}$ Technology Center of Changchun Customs, Changchun 130062, China

${ }^{\dagger}$ Corresponding author: J. Wang; wangjichun@ cjaas.com

Accepted for publication 3 May 2021

Funding

This work was supported by the Agricultural

Science and Technology Innovation Project of Jilin, China (grants CXGC2021TD002 and CXGC2017TD010), Jilin Province Outstanding Youth Fund Project (grant 20190103131JH), and Northeast Agricultural Research Center of China Postdoctoral Foundation (grant 188320)

The United States Department of Agriculture is an equal opportunity provider and employer.

$\boldsymbol{e}$-Xtra: Supplementary materials are available online.

The author(s) declare no conflict of interest.

\begin{abstract}
Rice blast disease caused by fungus Magnaporthe oryzae (syn. Pyricularia oryzae) is one of the most damaging diseases of rice, reducing plant production worldwide. In the present study, Bacillus subtilis strain GB519 was identified from the rhizosphere based on predicted signatures of 16 S ribosomal DNA and gyrA gene and morphological, biochemical, and physiological characteristics. Treated with B. subtilis GB519, rice plants exhibited increased germination rate, vigor index, shoot length, shoot fresh weight, and root fresh weight coupled with more production of indole acetic acid, organic phosphorus, and inorganic phosphorus. In culture, GB519 inhibited growth of the following rice fungal pathogens (in order from most effective to least effective): $M$. oryzae, Ustilaginoidea virens, Fusarium graminearum, F. moniliforme, F. oxysporum, and Rhizoctonia solani. Three years of studies showed that, when rice was sprayed with GB519, there were significant reductions in rice blast incidence in both the greenhouse and fields: 70.3 and $62.1 \%$ in $2017,69.9$ and $71.6 \%$ in 2018 , and 75.1 and $75.6 \%$ in 2019 , respectively. Such reductions were correlated with accumulated hydrolytic enzymes, including amylases, proteases, chitinase, and lipases, and the defense enzyme activity of the total antioxidant capacity, catalase, and superoxide dismutase in rice. Field experiments showed that the biocontrol efficacy of GB519 was similar to that of other biological and chemical fungicides. Our results indicate that $B$. subtilis strain GB519 promoted plant growth and reduced blast disease and suggest that this strain has potential to be used as a biological control agent against rice blast.
\end{abstract}

Keywords: Bacillus subtilis GB519, biocontrol, growth promotion, defense enzymes, Magnaporthe oryzae

Rice is one of the most important crops that feeds half of the world population. However, production of rice is limited by harmful fungal microbes such as Magnaporthe oryzae (syn. Pyricularia oryzae) causing rice blast, Rhizoctonia solani (teleomorph: Thanatephorus cucumeris) causing sheath blight, Cochliobolus miyabeanus (anamorph: Bipolaris oryzae) 
causing brown spot, Ustilaginoidea virens causing false smut, Tilletia barclayana (Neovossia horrida) causing kernel smut, and Cercospora janseana (teleomorph: Sphaerulina oryzina) causing narrow brown leaf spot (Ou 1985). Among them, rice blast is one of the most devastating disease that causes severe crop losses (Dean et al. 2005). Although growing blast-resistant rice cultivars is a cost-efficient strategy, rapid genetic mutations of $M$. oryzae affect the efficiency of newly deployed resistance (Jia et al. 2016; Miah et al. 2012). Fungicides such as isoprothiolane, edifenphos, and iprobenfos have been commonly used to prevent rice blast disease even though fungicide residues can cause environmental pollution and fungicide resistance is well documented in pathogen populations (Du et al. 2011; Lan et al. 2007; Xi et al. 2009; Yuan et al. 2005).

Beneficial microbes such as Bacillus subtilis associated with plants can help the plants grow faster and may protect them from the abovementioned harmful microbes (Todorova and Kozhuharova 2010). Extensive studies have been done with nitrogen fixation bacteria. The plant provides sugars to the nitrogen-fixing microorganism for nitrogen fixation and the microbe provides fixed nitrogen to the host plant for its growth as an exchange for these carbon sources (Momose et al. 2009). Beneficial microbes such as B. subtilis have demonstrated their superiority in their ability to colonize, reproduce, adapt, and help the growth of plants. For example, Harish et al. (2009) demonstrated that B. subtilis can control plant pathogens via secreting secondary metabolites. Filippi et al. (2011) discovered that B. subtilis promoted plant growth. Furthermore, B. subtilis strain T429 (Meng et al. 2015) and B. methylotrophicus strain BC79 (Shan et al. 2013) were demonstrated to be useful for reducing damage by $M$. oryzae. However, some mechanisms of antifungal activities and stimulating plant growth are largely unclear.

Understanding the mechanisms underlying B. subtilis on plant growth and antifungal activity will benefit the utilization of $B$. subtilis as a potential biological control agent for rice blast disease. The objectives of this study were to (i) specifically identify bacterial strain B. subtilis GB519 from the rhizosphere soil, (ii) assess its hydrolytic enzymes and plant growth promotion activities, (iii) evaluate the antifungal activity of GB519 on several other fungi in vitro, (iv) verify its efficacy against $M$. oryzae under greenhouse conditions, and (v) identify the production of defense enzymes.

\section{MATERIALS AND METHODS}

\section{Antagonistic bacterial strain and pathogens}

Bacterial strain GB519 was screened from healthy rice rhizosphere soils of rice blast disease-affected fields in Gongzhuling, northeastern China. Isolation and screening of antagonistic bacteria was carried out according to Shan et al. (2013). Strain GB519 had been stored at $-80^{\circ} \mathrm{C}$. Broths were prepared by selecting new single colonies of GB519 from nutrient agar plates, and inoculated in $5 \mathrm{ml}$ of nutrient broth and shaking culture for $48 \mathrm{~h}$ at $30^{\circ} \mathrm{C}$. Bacterial cell populations were adjusted to $10^{8} \mathrm{CFU} \mathrm{ml}{ }^{-1}$ with spectrophotometry (Abdallah et al. 2019); then, media consisting of peptone at $10 \mathrm{~g} / \mathrm{liter}$, sucrose at $10 \mathrm{~g} / \mathrm{liter}$, and agar at $16 \mathrm{~g} /$ liter were used in the following tests. Rice blast fungus (M. oryzae) was collected and kept at $-80^{\circ} \mathrm{C}$ and sporulated according to the methods of Wang et al. (2015). Other fungi such as $U$. virens, Sclerotinia sclerotiorum, Botrytis cinerea, Fusarium graminearum, F. moniliforme, F. oxysporum, Colletotrichum lagenarium, and Rhizoctonia solani used in this study were previously isolated, identified, and kept in our lab.

\section{Identification of bacterial strain GB519}

The morphological characteristics as well as biochemical and physiological properties of $B$. subtilis were determined as described by Garrity et al. (2004). The $16 \mathrm{~S}$ ribosomal DNA (rDNA) and the gyrA region were amplified by using two pairs of primers: $27-\mathrm{F}$ (5'-AGAGTTTGATCCTGGCTCAG-3') and 1492-R (5'-GG TTACCTTGTTACGACTT-3') (Islam et al. 2016) and gyrAF (5'-CAGTCAGGAAATGCGTACGTCCTT-3') and gyrA-R (5'-CAAGGTAATGCTCCAGGCATTGCT-3') (Chun and Bae 2000). PCRs were run with denaturation at $95^{\circ} \mathrm{C}$ for $3 \mathrm{~min}$; followed by 35 cycles of $95^{\circ} \mathrm{C}$ for $30 \mathrm{~s}, 55^{\circ} \mathrm{C}$ for $30 \mathrm{~s}$, and $72^{\circ} \mathrm{C}$ for $1 \mathrm{~min}$; with a final extension at $72^{\circ} \mathrm{C}$ for $10 \mathrm{~min}$. The gel-purified PCR products were ligated into pESI-T vector (Yeasen Biotech, Dalian, China) based on the manufacturer's instructions. The positive recombinant plasmids were purified with SanPrep Column Plasmid Mini-Preps Kit (Sangon Biotech, Dalian, China), digested with the restriction enzyme PstI and separated in a $1 \times$ Tris-acetate-EDTA agarose and visualized with Goldview (Solarbio Co., Ltd., Beijing, China). The predicted fragments were gel purified with SanPrep Column DNA Gel Extraction Kit (Sangon Biotech) and were sequenced by Sangon Biotech (Shanghai, China). The sequences were assembled using NCBI (https://www.ncbi.nlm.nih.gov/) and a phylogenetic tree of DNA sequence assemblies of $16 \mathrm{~S}$ rDNA and gyrA of GB519 was constructed using the neighbor-joining method in MEGA 7.0 software. The topology of the phylogenetic tree was constructed using 1,000 bootstrap resampling replicates (Kumar et al. 2016).

\section{Hydrolytic enzyme assays and plant growth activities in vivo}

The potential production of hydrolytic enzymes of strain GB519 was tested. Amylase activity was identified on $0.2 \%$ soluble starch agar plates at $30^{\circ} \mathrm{C}$ for $48 \mathrm{~h}$ (Mishra and Behera 2008). The protease activity was tasted on medium containing $1 \%$ skim milk at $30^{\circ} \mathrm{C}$ for $48 \mathrm{~h}$ (Yu et al. 2017). Chitinase activity was evaluated using $0.5 \%$ chitin-agar medium after the plates were incubated at $30^{\circ} \mathrm{C}$ for $96 \mathrm{~h}$ (Chernin and Chet 2002). Lipase was evaluated using nutrient agar medium supplemented with $1 \%$ olive oil emulsion and $0.1 \%$ rhodamine $\mathrm{B}$ at $30^{\circ} \mathrm{C}$ for $48 \mathrm{~h}$ (Kravchenko et al. 2002). Glucanase activity was tested at $30^{\circ} \mathrm{C}$ for $72 \mathrm{~h}$, after adding $0.5 \% \beta-1,3$-glucan in a semisolid nitrogen-free medium (Fan et al. 2002; Renwick et al. 1991). Organic phosphate solubilization was evaluated with $0.02 \%$ egg lecithin agar medium for organic phosphorus at $30^{\circ} \mathrm{C}$ for 72 h. Phosphate solubilization was evaluated with $0.5 \%$ $\mathrm{Ca}_{3}\left(\mathrm{PO}_{4}\right)_{2}$ agar medium for inorganic phosphorus at $30^{\circ} \mathrm{C}$ for 3 days (Mehta and Nautiyal 2001). Indole-3-acetic acid (IAA) production was measured by adding Salkowsky's reagent to the supernatant of stain GB519 (Bibi et al. 2012).

The hydrogen cyanide (HCN) was assessed qualitatively on nutrient agar medium supplemented with $0.45 \%$ glycine at $30^{\circ} \mathrm{C}$ for $72 \mathrm{~h}$ (Aydi Ben Abdallah et al. 2016; Lorck 1948). Siderophore production was detected on $0.12 \%$ chrome azurol-S agar medium at $30^{\circ} \mathrm{C}$ for $48 \mathrm{~h}$ (Shin et al. 2001).

\section{Effect on rice seed}

Twenty-five rice seeds were disinfected and treated with broth of GB519 $\left(10^{8} \mathrm{CFU} \mathrm{ml} \mathrm{m}^{-1}\right)$ for $2 \mathrm{~h}$. After seed were dried in air under sterilized conditions, they were placed on two layers of sterilized filter papers with more than $90 \%$ humidity in sterilized 
petri dishes; appropriate sterilized water was added when necessary. The petri dishes with seed were incubated in an incubator under a day and night cycle of 16 and $8 \mathrm{~h}$, respectively, at $25^{\circ} \mathrm{C}$. The two controls were (i) $20 \mathrm{ml}$ of a concentration of $2.5 \mathrm{~g} / \mathrm{liter}$ (400 times) of liquid of chemical fungicide with $20 \%$ iprobenfos. tricyclazole (Beijing Green Agricultural Science and Technology Group Co., Ltd.) and (ii) sterile water. The number of seeds that germinated, root length, and shoot length were measured on the 14th day after treatment. The experiment was conducted with three replicates in each treatment. The vigor index (VI) was calculated using the following formula: VI $=$ (mean shoot length + mean root length) $\times$ germination (\%) (Abdul-Baki and Anderson 1973)

\section{Effect on rice growth}

Ten rice seedlings at approximately the fourth leaf stage were planted in plastic pots filled with sterilized paddy soils. Seedlings grown in a greenhouse were sprayed with $20 \mathrm{ml}$ of broth of GB519 at $1 \times 10^{8} \mathrm{CFU} \mathrm{m}{ }^{-1}$ and $25^{\circ} \mathrm{C}$. The two controls were (i) $20 \mathrm{ml}$ of a concentration of $2.5 \mathrm{~g} /$ liter (400 times) of liquid of chemical fungicide of $20 \%$ iprobenfos tricyclazole (Beijing Green Agricultural Science and Technology Group Co., Ltd.) and (ii) sterile water. Each treatment had three replicates and the experiment was performed three times at different times. The growth characteristics, including the length, fresh weight, and dry weight of shoots and roots, were measured at 30 days after treatment.

\section{In vitro antifungal assays}

The confrontation culture method was performed to conform the effects of GB519 on plant pathogen growth and development. GB519 was tested against M. oryzae, U. virens, S. sclerotiorum, $B$. cinerea, $F$. graminearum, $F$. moniliforme, $F$. oxysporum, $C$. lagenarium, and $R$. solani. For evaluation, a 5-mm mycelium plug of each of nine pathogens was placed at the center of a potato dextrose agar plate and drops of $10 \mu \mathrm{l}$ of broth of GB519 $\left(10^{8} \mathrm{CFU}\right.$ $\mathrm{ml}^{-1}$ ) were placed at two opposite points, each $25 \mathrm{~mm}$ from center, and incubated at $25^{\circ} \mathrm{C}$ in darkness. Control inoculation was a 5-mm-diameter block carrying mycelia of each pathogenic fungus without GB519 in the plate. When mycelial growth in the control plate reached the edge of the plate, the distance between the edge of blast to the edge of bacteria of the treated plate between the two inoculation sites (GB519 and fungal block) was measured. The experiment was performed in three replications and was repeated two times. The formula of inhibition rate was calculated as described by Montealegre et al. (2003).

\section{Use GB519 to control rice leaf blast in the greenhouse}

Because GB519 was effective against $M$. oryzae in the lab, 200 rice seedlings at the four-leaf stage were used for efficacy assays using replicated pot experiments $(600$ by 300 by $30 \mathrm{~mm}$ ) under greenhouse conditions of $60 \%$ humidity and $25^{\circ} \mathrm{C}$. Seedlings were first sprayed with $20 \mathrm{ml}$ of broth of GB519 at $1 \times 10^{8} \mathrm{CFU} \mathrm{ml}{ }^{-1}$; then, they were treated with a 20-ml conidial suspension of $M$. oryzae at $5 \times 10^{5}$ conidia ml $^{-1}$ pot $^{-1}$ using the following scheme: (i) $24 \mathrm{~h}$ after GB519 treatment, (ii) $24 \mathrm{~h}$ after chemical fungicide with $20 \%$ iprobenfos-tricyclazole, and (iii) $24 \mathrm{~h}$ after spraying the same volume of water by an artificial sprayer. The experiment was performed with three replications for each treatment and was repeated two times in three different years $(2017,2018$, and 2019). The incubation conditions in the greenhouse were maintained at 20 to $30^{\circ} \mathrm{C}$ with $12 \mathrm{~h}$ of light and $12 \mathrm{~h}$ of darkness for disease development (Wang et al.
2013). The disease index was measured 7 days after inoculation following the method of Prabavathy et al. (2006). Specifically, the blast scores were recorded according to the 0-to-9 scale rating system described by Wang et al. (2013). Specifically, the index of diseased leaf (IDL) and the biocontrol efficacy were calculated by the following formulas: IDL $(\%)=\sum$ (number of different scale $\times$ value of different scale)/(all number of test $\times$ the value of the highest scale $) \times 100$, and biocontrol efficacy $(\%)=($ IDL of water treatment - IDL of test treatment)/IDL of water treatment $\times 100$.

\section{Use GB519 to control rice blast in the field}

To study the biocontrol efficacy of GB519 against rice blast under field conditions in northeastern China, the field experiments were carried out in a rich field with a known history of heavy rice blast infection in Meihekou City, Jilin Province, China $\left(125^{\circ} 77^{\prime} \mathrm{N}\right.$, $42^{\circ} 63^{\prime} \mathrm{E}$ ) in 2017,2018 , and 2019. All agronomical practices were carried out normally before rice reached heading stage in the field. The field was divided into 12 plots, and each plot was $100 \mathrm{~m}^{2}$. A completely randomized design was arranged with three replicate plots for three treatments. The treatments were as follows: (i) broth of GB519 $\left(1 \times 10^{8} \mathrm{CFU} \mathrm{ml}^{-1}, 15\right.$ liters per $\left.667 \mathrm{~m}^{2}\right)$, (ii) $20 \%$ iprobenfos tricyclazole (120 g per $\left.667 \mathrm{~m}^{2}\right)$, and (iii) the control. The disease index and biocontrol efficacy were calculated on the 14th day according to Meng et al. (2015). Specifically, the blast scores were recorded according to the number of diseased panicles, and the rate of diseased panicles (RDP) and the biocontrol efficacy were calculated by the following formulas: RDP $(\%)=$ (number of diseased panicles/total number of panicles) $\times 100$, and biocontrol efficacy $(\%)=($ RDP of water treatment - RDP of test treatment)/RDP of water treatment $\times 100$.

\section{Rice defense enzyme assays}

To elucidate biochemical mechanisms of induced rice defense, we performed the defense enzyme assays of rice seedlings against $M$. oryzae under greenhouse conditions. The greenhouse-grown 30-day-old rice seedlings at the four-leaf stage were used to detect defense enzymes. Each treatment contained three replicates and the experiment was performed three times at different times. The leaves were sampled at different time intervals $(0,6,12,24,36$, 48, 72, and $96 \mathrm{~h}$ ) after inoculation, frozen using liquid nitrogen, and stored in a freezer $\left(-70^{\circ} \mathrm{C}\right)$. The experiment was performed in three replications. The activities of defense-related enzymes, including superoxide dismutase (SOD) and catalase (CAT), and total antioxidant capacity (TAOC) were measured with an enzyme assays kit from Jiancheng Bioengineering Institute (category numbers A001-1-2, A007-1-1, and A015-3-1; Nanjing, China).

\section{Statistical analysis}

The assay experiments were repeated three times simultaneously. Statistical analysis was performed with the SPSS 19.0 software (SPSS, Chicago, IL, U.S.A.). The value of $P<$ 0.05 was used to declare the statistical significance. All data were expressed as mean \pm standard deviation.

\section{RESULTS}

\section{Identification of the GB519 strain}

The bacterial strain GB519 was a Gram-positive bacterium with a peritrichous, single rod cell. On nutrient agar medium, 
the GB519 formed creamy white colonies, with a matte surface and rough colony margins (Supplementary Fig. S1A). Scanning and transmission electron microscopy showed that GB519 cells are rod shaped (Supplementary Fig. S1B and C). Also, the phylogenetic trees derived from the 16S rDNA (MT271920.1) and gyrA (MT294310.1) sequences of strain GB519 were clustered with other B. subtilis strains (Supplementary Figs. S1D and S2A and B). Furthermore, the physicochemical indexes of strain GB519 were tested, with results in Supplementary Table S1. Taken together, these data indicate that GB519 belongs to Bacillus subtilis.

\section{The extracellular enzyme activity and plant growth-promoting ability}

The B. subtilis GB519 strain was verified to produce amylase, protease, chitinase, and lipase on $0.2 \%$ soluble starch, skim milk, chitin, and polyvinyl alcohol plus olive oil agar medium, respectively (Fig. 1A to D). The B. subtilis GB519 strain showed clear zones around colonies on organic phosphorus and inorganic phosphorus agar medium (Fig. 1E and F). Furthermore, the IAA plant growth hormone was detected $48 \mathrm{~h}$ after incubation (Fig. 1G). All of these observed characteristics suggest that GB519 promotes plant growth even though glucanase activity, $\mathrm{HCN}$, and siderophore production were not detected.

\section{The effect on rice seed germination and seedling vigor}

The germination rate of rice seed treated with $B$. subtilis GB519 was $90.2 \%$, which was $4.6 \%$ higher than water control and $62.5 \%$ higher than that in the iprobenfos.tricyclazole treatment (Table 1). Similarly, the highest VI was 6,719.2 for rice seed treated with GB519 (Table 1), and it was significantly higher than the water control and iprobenfos-tricyclazole treatment, increased by 33.1 and $913.2 \%$, respectively. These results suggest that GB519 improves germination and vigor of rice seedlings.

\section{The effect on rice growth under greenhouse conditions}

Rice treated by B. subtilis GB519 had higher growth compared with treatments using iprobenfos.tricyclazole or the water control. Treatment with GB519 produced shoot length, shoot fresh weight, and root fresh weight of $186.3 \mathrm{~mm}$ plant $^{-1}$, $115.9 \mathrm{mg}$ plant $^{-1}$, and $47.0 \mathrm{mg}$ plant $^{-1}$, corresponding to an increase of $10.6,46.5$, and $76.7 \%$ above water control, respectively (Table 2).

\section{Antifungal activity}

Nine different plant fungal pathogens were used to verify the antifungal activity of $B$. subtilis GB519. Inhibition diameters and ratio are shown in Figure 2 and Supplementary Table S2. The GB519 inhibited the mycelial growth of all nine fungal pathogens, including the rice-disease-causing agents $M$. oryzae, $U$. virens $(87.4 \%), F$. graminearum $(67.8 \%), F$. moniliforme (60.2\%), F. oxysporum (55.0\%), and R. solani (55.0\%), at varying degrees within $40.0 \mathrm{~mm}$ with inhibition ratios greater than $55.0 \%$. Among them, the strongest inhibitory effect of GB519 was against $M$. oryzae, with an inhibition ratio of $89.7 \%$.

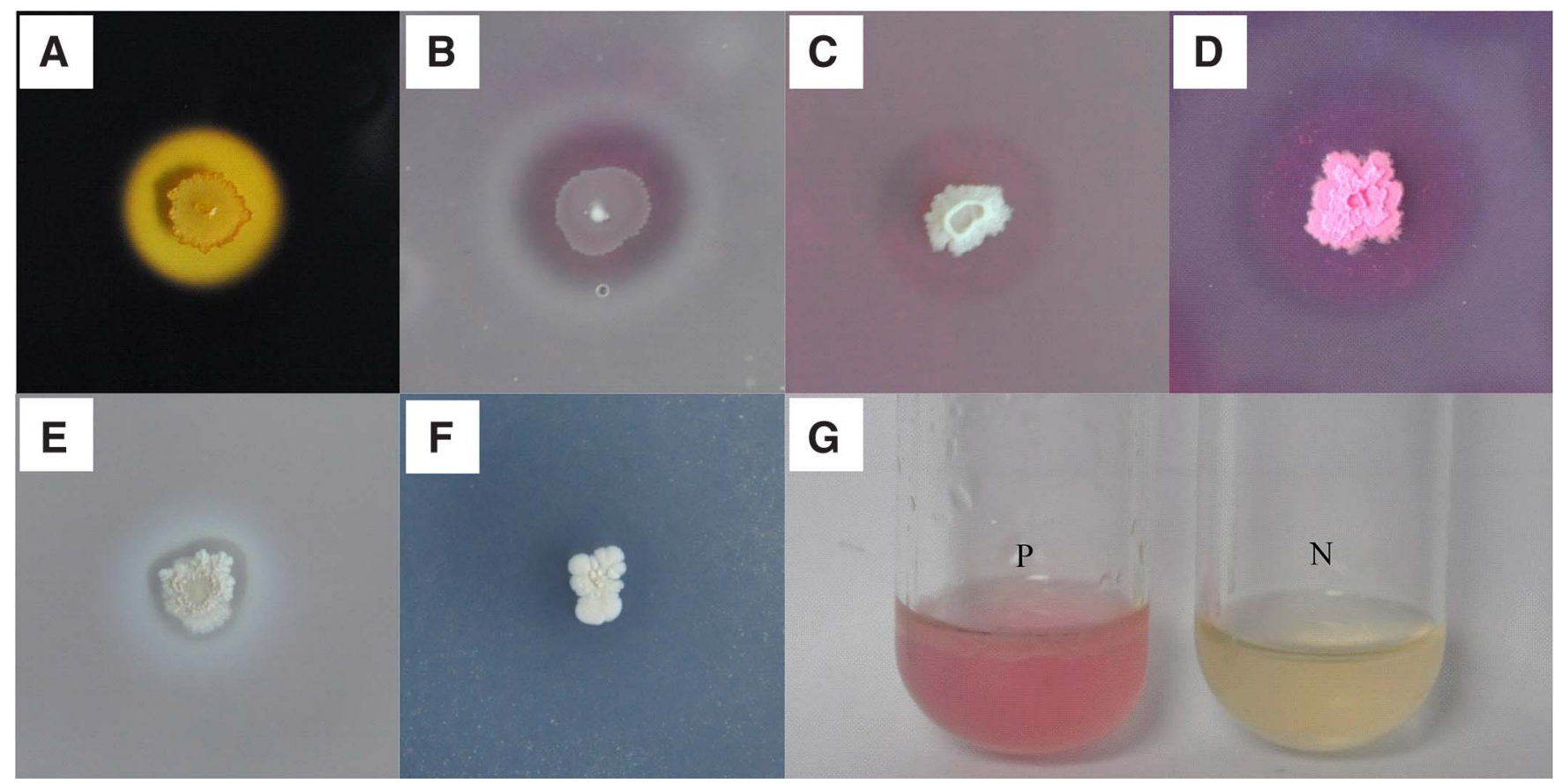

\section{FIGURE 1}

Photographic presentations of tested enzymes, phosphate solubilization, and indole-3-acetic acid (IAA) produced by strain GB519. A, Amylase activity is shown as a clear zone formation on $0.2 \%$ soluble starch agar plates. B, Protease is shown as a clear zone formation around the colony on medium containing $1 \%$ skim milk. C, Chitinase was evaluated and the zones of chitin clearing occurred around the colonies after incubated at $30^{\circ} \mathrm{C}$ for $96 \mathrm{~h}$ on $0.5 \%$ chitin-agar medium. D, Lipase was evaluated and presented as a clear pink halo exhibited on the plate after incubation at $30^{\circ} \mathrm{C}$ for $48 \mathrm{~h}$ on nutrient agar medium supplemented with $1 \%$ olive oil emulsion and $0.1 \%$ rhodamine $\mathrm{B}$. E, Organic phosphate solubilization was evaluated with a translucent milky white growth using $0.02 \%$ egg lecithin agar medium for organic phosphorus. F, Phosphate solubilization was evaluated with clearing zones around the colony using $0.5 \% \mathrm{Ca}_{3}\left(\mathrm{PO}_{4}\right)_{2}$ agar medium for inorganic phosphorus at $30^{\circ} \mathrm{C}$ for 3 days. G, IAA measured as a positive reaction $(\mathrm{P})$ had pink color compared with the negative control $(\mathrm{N})$ in broth of GB519 after Salkowsky's reagent was added to the supernatant of strain GB519. 


\section{Biocontrol of rice leaf blast by GB519 in greenhouse experiments}

Because GB519 was the most inhibitory to M. oryzae, we examined the use of GB519 to control rice leaf blast by measuring the disease index after GB519 treatments under greenhouse experiments in 3 years. The disease index of rice blast disease treated with GB519 was 22.9 in 2017, 25.0 in 2018, and 16.9 in 2019, which was significantly lower than that of the water control (77.4 in 2017, 83.0 in 2018, and 67.9 in 2019), respectively

TABLE 1

Effects of GB519 on rice seed germination and seedling vigor ${ }^{\mathrm{x}}$

\begin{tabular}{lcccc}
\hline Treatment $^{\mathrm{y}}$ & GR $(\%)$ & $\begin{array}{c}\text { Increase of } \\
\text { GR }(\%)\end{array}$ & $\mathrm{VI}^{\mathrm{z}}$ & \multicolumn{2}{c}{$\begin{array}{c}\text { Increase of } \\
\text { VI }(\%)\end{array}$} \\
\hline Water control & $86.4 \pm 4.2 \mathrm{a}$ & - & $5,100.1 \pm 545.3 \mathrm{~b}$ & - \\
GB519 & $90.2 \pm 2.0 \mathrm{a}$ & 4.6 & $6,719.2 \pm 654.1 \mathrm{a}$ & 33.1 \\
Iprobenfos.tricyclazole & $55.5 \pm 7.9 \mathrm{~b}$ & -35.4 & $663.2 \pm 230.1 \mathrm{c}$ & -86.6 \\
\hline
\end{tabular}

${ }^{x} \mathrm{GR}=$ germination rate and VI = vigor index. Means \pm standard error followed by the same letter do not differ significantly according to Duncan's multiple range test at $P<0.05$.

${ }^{\mathrm{y}}$ Rice seed with different treatments were placed on two layers of sterilized filter papers and incubated in an incubator under a cycle of $16 \mathrm{~h}$ (day) and $8 \mathrm{~h}$ (night) at $25^{\circ} \mathrm{C}$; then, the data of seed germination, shoot length, and root length were collected on the 14th day.

${ }^{\mathrm{z}}$ VI was calculated using shoot length, root length, and GR.

TABLE 2

Growth promotion activity of GB519 on rice under greenhouse conditions ${ }^{2}$

\begin{tabular}{lcccccc}
\hline Treatment & $\begin{array}{c}\text { Shoot length } \\
(\mathrm{mm})\end{array}$ & $\begin{array}{c}\text { Shoot FW } \\
(\mathrm{mg} / \mathrm{plant})\end{array}$ & $\begin{array}{c}\text { Shoot DW } \\
(\mathrm{mg} / \mathrm{plant})\end{array}$ & $\begin{array}{c}\text { Root length } \\
(\mathrm{mm})\end{array}$ & $\begin{array}{c}\text { Root FW } \\
(\mathrm{mg} / \mathrm{plant})\end{array}$ & $\begin{array}{c}\text { Root DW } \\
(\mathrm{mg} / \mathrm{plant})\end{array}$ \\
\hline Water control & $168.5 \pm 1.9 \mathrm{~b}$ & $79.2 \pm 20.7 \mathrm{~b}$ & $24.8 \pm 5.5 \mathrm{a}$ & $78.4 \pm 19.9 \mathrm{a}$ & $26.6 \pm 7.8 \mathrm{~b}$ & $11.4 \pm 0.4 \mathrm{a}$ \\
GB519 & $186.3 \pm 8.9 \mathrm{a}$ & $115.9 \pm 10.0 \mathrm{a}$ & $27.4 \pm 1.8 \mathrm{a}$ & $99.3 \pm 5.0 \mathrm{a}$ & $47.0 \pm 9.9 \mathrm{a}$ & $12.4 \pm 1.6 \mathrm{a}$ \\
Iprobenfos.tricyclazole & $159.5 \pm 8.2 \mathrm{~b}$ & $75.3 \pm 0.7 \mathrm{~b}$ & $23.9 \pm 1.9 \mathrm{a}$ & $76.1 \pm 21.6 \mathrm{a}$ & $29.3 \pm 1.9 \mathrm{~b}$ & $13.5 \pm 1.3 \mathrm{a}$ \\
\hline
\end{tabular}

${ }^{\mathrm{z}}$ Growth characteristics, including the length, fresh weight (FW), and dry weight (DW) of shoots and roots, were measured on 30th day, after rice seedlings were treated at approximately the fourth-leaf stage in a greenhouse. Means \pm standard error followed by the same letter do not differ significantly according to Duncan's multiple range test at $P<0.05$.
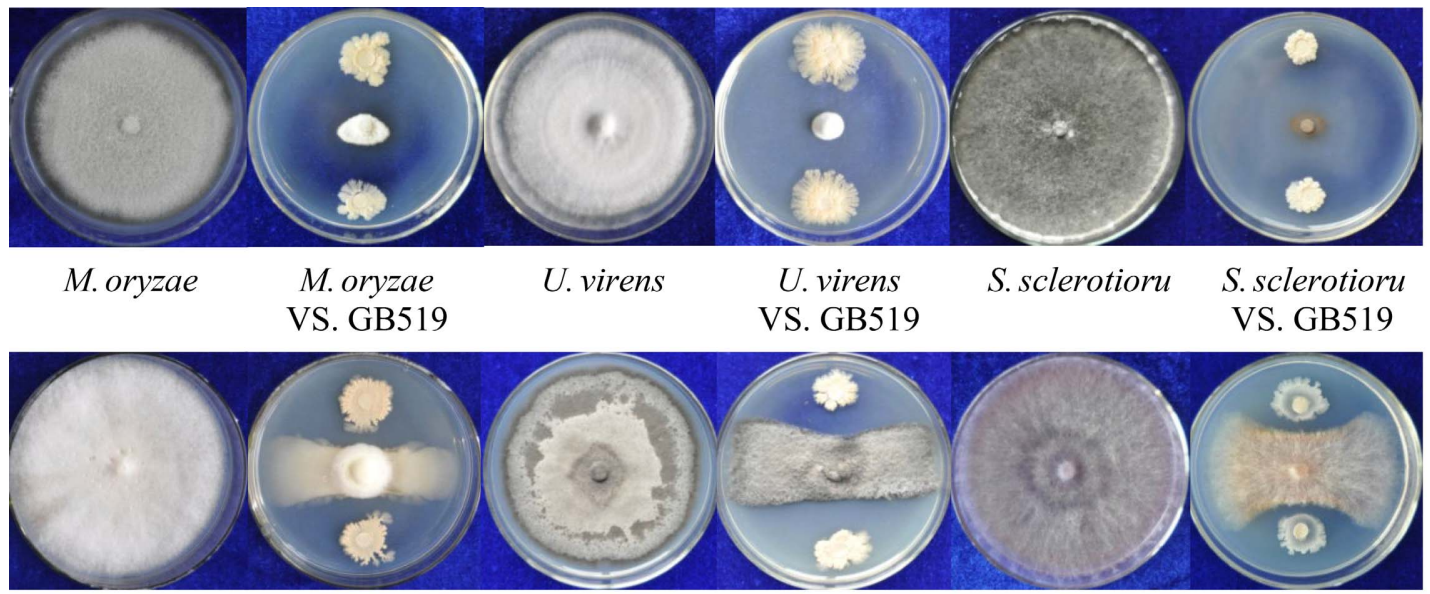
B. cinerea
B. cinerea
C. lagenarium
C. lagenarium
F.graminearum F.graminearum VS. GB519 VS. GB519
VS. GB519

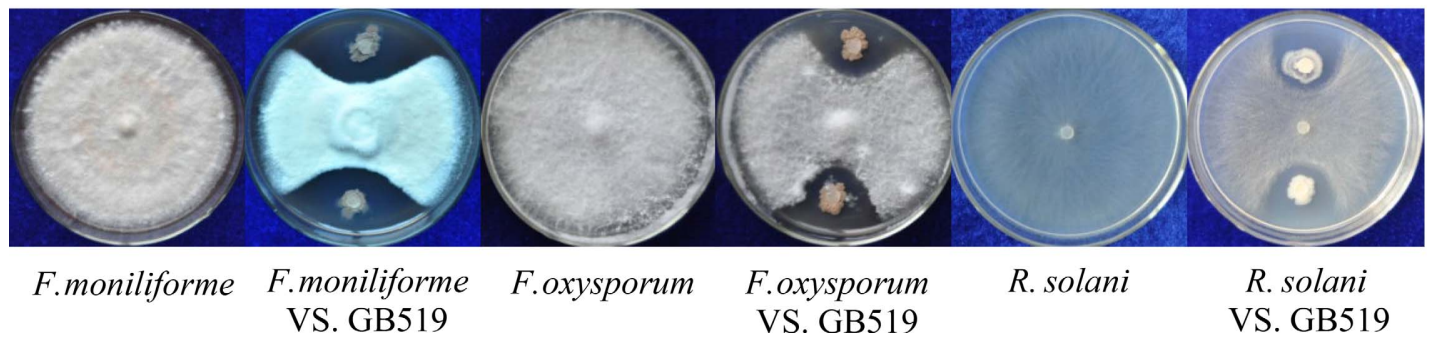

FIGURE 2

In vitro inhibition by strain GB519 against nine plant pathogens: Magnaporthe oryzae, Ustilaginoidea virens, Sclerotinia sclerotiorum, Botrytis cinerea, Fusarium graminearum, F. moniliforme, F. oxysporum, Colletotrichum lagenarium, and Rhizoctonia solani. For evaluation, a mycelium plug of a pathogenic fungus was placed at the center of a potato dextrose agar plate and drops of $10 \mu \mathrm{l}$ of broth of GB519 $\left(10^{8} \mathrm{CFU} \mathrm{ml}{ }^{-1}\right)$ were placed at two opposite points with the plug as center, then incubated at $25^{\circ} \mathrm{C}$ in darkness. The distance from the two inoculation points of GB519 to fungal plug was measured after mycelial growth in the control reached the edge of plate. 
(Table 3). There was no significant difference in disease index between GB519 and iprobenfos-tricyclazole treatments. However, the GB519 treatment had a higher biocontrol efficacy of $70.3,69.9$, and $75.1 \%$, respectively, in the 3 years, which was similar to that of the chemical fungicide (Table 3 ).

\section{Biocontrol of rice blast disease by GB519 in field experiments}

In field experiments, the application of B. subtilis GB519 reduced the spread of rice blast disease in 2017, 2018, and 2019. The disease index of rice blast with GB519 was 1.95 in $2017,2.47$ in 2018, and 2.10 in 2019, and the biocontrol efficacy was $62.1,71.6$, and $75.6 \%$, respectively. The treatments with GB519 were as effective as the $20 \%$ iprobenfos-tricyclazole at $120 \mathrm{~g}$ per $667 \mathrm{~m}^{2}$ during the 3 years of experiments (Table 3 ).

\section{Induction of defense enzymes in rice after blast infection}

The TAOC and enzymatic activity of the CAT and SOD increased $6 \mathrm{~h}$ after inoculation and reached the maximum at $36 \mathrm{~h}$ for TAOC, $24 \mathrm{~h}$ for CAT, and $24 \mathrm{~h}$ for SOD after rice plants were sprayed with B. subtilis GB519 (Fig. 3). There were significantly higher activities in the GB519 treatment than iprobenfos-tricyclazole and water control treatments at 12 and $24 \mathrm{~h}$ after inoculation. In rice plants treated with GB519 and $M$. oryzae, TAOC increased $1.5 \times$, CAT increased $3.5 \times$, and SOD increased $1.8 \times$ compared with the control, suggesting that transient inductions of these defense enzymes are responsible for reducing blast disease damages.

\section{DISCUSSION}

Biological control has become an efficient, alternative, and ecologically friendly method for plant disease management (Kumar et al. 2017; Niu et al. 2013). We identified and determined that the B. subtilis GB519 strain could be used as an effective biological control agent to prevent rice blast disease. We showed that B. subtilis GB519 accelerated plant growth in vitro by producing more IAA, inorganic phosphorus solubilization, and extracellular lipase (Table 2; Fig. 2). Our findings are consistent with the notion that Bacillus spp. may play important roles in supplying more soluble phosphorus to plants (Beneduzi et al. 2008; Goteti et al. 2013; Jorquera et al. 2008). Additionally, we also demonstrated that GB519 solubilized phosphate and promoted plant growth similar to that of a plant growth stimulator. Furthermore, the increased accumulations of IAA could accelerate nutrient movements that can benefit phosphate utilization for plant growth. Previously, Bacillus spp. such as B. amyloliquefaciens PPB4 (Islam et al. 2016), B. cereus S42 (Aydi Ben Abdallah et al. 2016), and B. methylotrophicus H8 (Almoneafy et al. 2012) were also reported to produce IAA at concentrations of $50.18,26.49$, and $59.56 \mu \mathrm{g} \mathrm{ml}^{-1}$, respectively, which is similar to what we found with B. subtilis GB519.

A number of Bacillus strains, including GB519, were capable of promoting plant growth and also producing biofilms on plant surfaces, enabling antagonistic activities against various plant pathogens (Chen et al. 2013; Gao et al. 2015; Lin et al. 2017). For example, B. methylotrophicus BC79 (Shan et al. 2013) and B. cereus (Tokpah et al. 2016) were shown to reduce blast disease, and B. pumilus GLB197 reduced grapevine downy mildew (Zhang et al. 2017). In this study, we also found abilities of Bacillus strains pertaining to biofilms (data not shown). Together, these findings support our hypothesis that GB519 is a good candidate to control rice blast fungus.

Plants utilize multiple defense pathways, including reactive oxygen species and antioxidant defense pathways, to fight off stresses (Hasanuzzaman et al. 2020). Previously, defense enzymes, including protease, chitinase, and lipase, were shown to degrade and lyse pathogenic fungal cells (Bibi et al. 2012; Muleta et al. 2007; Thampi and Bhai 2017; Tiru et al. 2013). Numerous Bacillus spp. were effective to control plant diseases on various crops, and mechanisms were largely unclear (Chithrashree et al. 2011). In the present study, GB519 was shown to accelerate the production of plant defense enzymes CAT, SOD, and TAOC and to inhibit $M$. oryzae growth and infection. The enzymes such as CAT, SOD, and TAOC are known to be mainly involved in the antioxidant defense pathway. These findings suggest that GB519 activates the antioxidant defense pathway in order to restrict $M$. oryzae growth and infection.

In the present study, we demonstrated that the severity of rice blast disease was reduced by using GB519 during 3 years under greenhouse and field conditions (Table 3). The suppression of rice blast by spraying GB519 was as effective as that by spraying the chemical fungicide iprobenfos tricyclazole. Our results are consistent with previous studies. B. subtilis T429 dry flowable had no significant differences in disease biocontrol efficacy compared with $75 \%$ tricyclazole (Meng et al. 2015). Filippi et al. (2011) showed that spraying Rizo-52 2 days before pathogen inoculation significantly suppressed leaf blast by $86 \%$. Rice plants treated with

TABLE 3

Biocontrol efficacy of GB519 against rice blast disease under greenhouse and field conditions ${ }^{2}$

\begin{tabular}{|c|c|c|c|c|c|c|}
\hline \multirow[b]{2}{*}{ Treatment } & \multicolumn{2}{|c|}{2017} & \multicolumn{2}{|c|}{2018} & \multicolumn{2}{|c|}{2019} \\
\hline & $\begin{array}{l}\text { Disease } \\
\text { index }\end{array}$ & $\begin{array}{l}\text { Biocontrol } \\
\text { efficacy (\%) }\end{array}$ & $\begin{array}{l}\text { Disease } \\
\text { index }\end{array}$ & $\begin{array}{l}\text { Biocontrol } \\
\text { efficacy (\%) }\end{array}$ & $\begin{array}{l}\text { Disease } \\
\text { index }\end{array}$ & $\begin{array}{l}\text { Biocontrol } \\
\text { efficacy }(\%)\end{array}$ \\
\hline \multicolumn{7}{|l|}{ Greenhouse } \\
\hline Water control & $77.4 \pm 3.1 \mathrm{a}$ & - & $83.0 \pm 1.7 \mathrm{a}$ & - & $67.9 \pm 2.8 \mathrm{a}$ & - \\
\hline GB519 & $22.9 \pm 2.9 \mathrm{~b}$ & 70.3 & $25.0 \pm 2.3 \mathrm{~b}$ & 69.9 & $16.9 \pm 2.2 \mathrm{~b}$ & 75.1 \\
\hline Iprobenfos-tricyclazole & $24.5 \pm 3.4 \mathrm{~b}$ & 68.3 & $21.4 \pm 2.1 \mathrm{~b}$ & 74.2 & $18.0 \pm 1.4 \mathrm{~b}$ & 73.5 \\
\hline \multicolumn{7}{|l|}{ Field } \\
\hline Water control & $5.16 \pm 0.62 \mathrm{a}$ & - & $8.79 \pm 0.73 \mathrm{a}$ & - & $8.59 \pm 0.58 \mathrm{a}$ & - \\
\hline GB519 & $1.95 \pm 0.18 b$ & 62.1 & $2.47 \pm 0.30 \mathrm{~b}$ & 71.6 & $2.10 \pm 0.24 \mathrm{~b}$ & 75.6 \\
\hline Iprobenfos tricyclazole & $1.71 \pm 0.07 \mathrm{~b}$ & 66.5 & $2.33 \pm 0.40 b$ & 73.3 & $2.19 \pm 0.25 b$ & 74.3 \\
\hline
\end{tabular}

${ }^{\mathrm{z}}$ Seedlings with approximately four leaves in a greenhouse and plants in a field were used for efficacy assays: (i) $24 \mathrm{~h}$ after GB519 treatment, (ii) $24 \mathrm{~h}$ after chemical fungicide with $20 \%$ iprobenfos tricyclazole, and (iii) $24 \mathrm{~h}$ after spraying the same volume of water by an artificial sprayer. Disease indices of seedlings and plants were assessed 7 and 14 days after inoculation, respectively. Means \pm standard error followed by the same letter do not differ significantly according to Duncan's multiple range test at $P<0.05$. 
Rizo-46 and Rizo-55 greatly increased enzymes activities of peroxidase, $\beta$-1,3-glucanase, and chitinase that were correlated with suppression of leaf blast disease. Furthermore, a bit of difference in GB519 biocontrol efficacy compared with the chemical iprobenfos-tricyclazole among the 3 years might have resulted from the effect of climate conditions such as the temperature, sunshine, and moisture, which should be considered as important affecting factors when using biocontrol products.

In the present study, we showed significant increases in the defense enzymes- $1.5 \times$ for TAOC at $36 \mathrm{~h}, 3.5 \times$ for CAT at
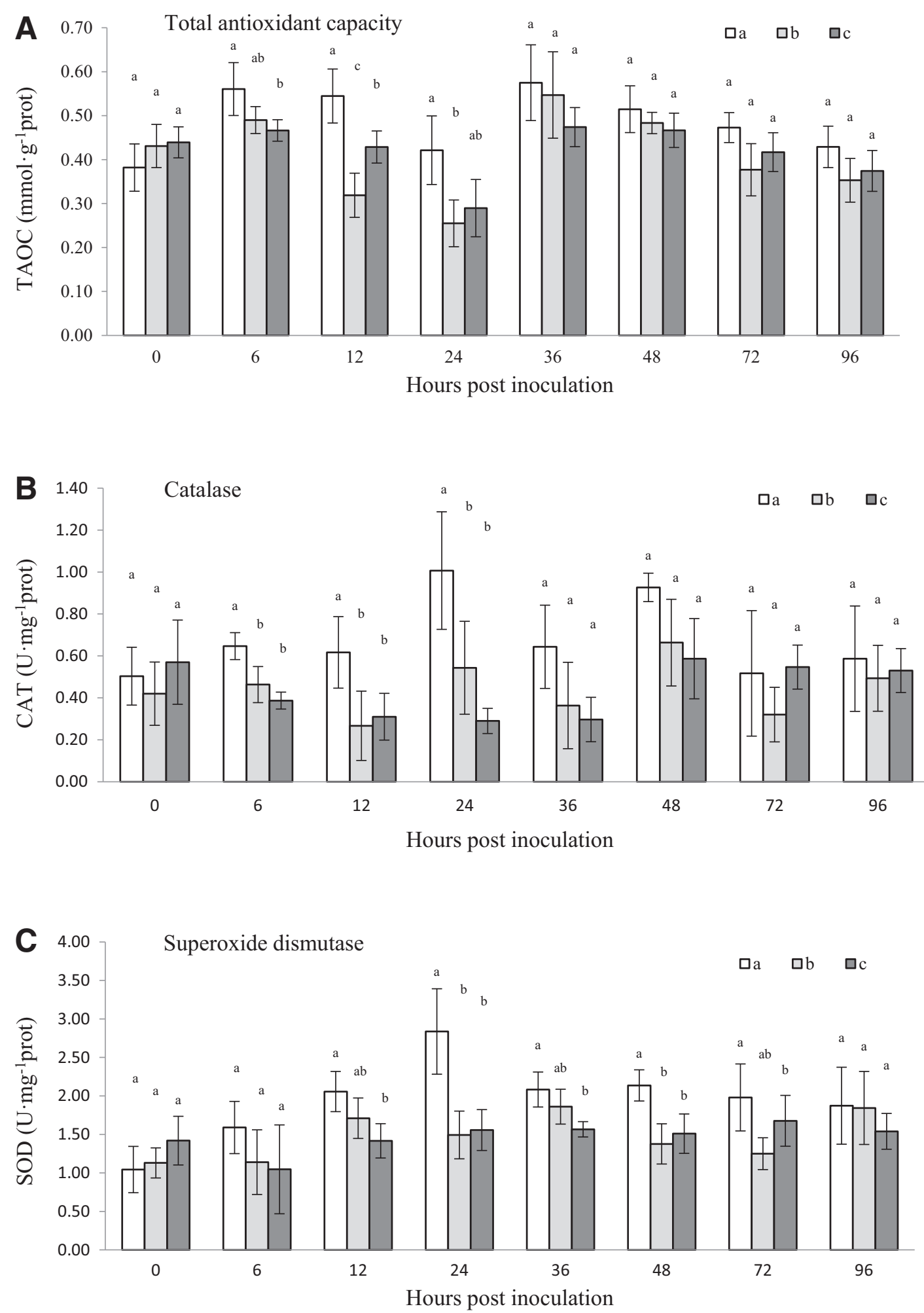

FIGURE 3

Enzymatic activity of rice plants with different treatments on A, total antioxidant capacity (TAOC); $\mathbf{B}$, catalase (CAT); and C, superoxide dismutase (SOD). Lowercase letters: a = Magnaporthe oryzae was sprayed $24 \mathrm{~h}$ after GB519 treatment; $\mathrm{b}=$ M. oryzae was sprayed 24 $\mathrm{h}$ after chemical fungicide with $20 \%$ iprobenfos tricyclazole; and c $=M$. oryzae was sprayed $24 \mathrm{~h}$ after the same volume of water. Error bars show standard deviations for triplicate assays. The $x$-axis indicates different time points after inoculation and $y$-axis indicates enzymatic activity level. Values in the same column followed by the same letter are not statistically different by Duncan's multiple range test $(P<0.05)$. 
$24 \mathrm{~h}$, and $1.8 \times$ for SOD at $24 \mathrm{~h}$-compared with that of the control in rice plants first treated with GB519 and then inoculated with $M$. oryzae. The results demonstrated that these increased enzymatic activities affected plant growth and suggested that they were correlated with rice blast suppression under greenhouse conditions.

In conclusion, we showed that GB519 can promote plant growth and prevent rice blast disease as effectively as one of the most-used fungicides and also demonstrated that GB519 can inhibit nine plant pathogens, including $R$. solani (teleomorph: Thanatephorus cucumeris) causing sheath blight, $F$. graminearum and $F$. oxysporum causing rice blight, $F$. moniliforme causing rice bakanae, and $U$. virens causing false smut, in addition to M. oryzae. This suggests that GB519 is a broad-spectrum biocontrol agent for rice diseases. We also presented evidence of inhibitory effects on pathogens C. lagenarium, Botrytis cinerea, and $S$. sclerotiorum causing vegetable diseases, which suggests that GB519 has potential to be a broad-spectrum biocontrol agent. We showed that GB519 hijacked the antioxidant defense pathway to prevent the infections by $M$. oryzae. Further studies are required on topics such as methods for large-scale production, formulation, preservation conditions, shelf life and application, the mode of action, phytotoxicity, safety, and cost efficiency under both greenhouse and field conditions.

\section{ACKNOWLEDGMENTS}

We thank the United States Department of Agriculture-Agricultural Research Service for continuous collaboration of with Jilin Academy of Agricultural Sciences.

\section{LITERATURE CITED}

Abdallah, Y., Yang, M., Zhang, M., Masum, Md. M. I., Ogunyemi, S. O., Hossain, A., An, Q., Yan, C., and Li, B. 2019. Plant growth promotion and suppression of bacterial leaf blight in rice by Paenibacillus polymyxa Sx3. Lett. Appl. Microbiol. 68:423-429.

Abdul-Baki, A. A., and Anderson, J. D. 1973. Vigor determination in soybean seed by multiple criteria. Crop Sci. 13:630-633.

Almoneafy, A. A., Xie, G. L., Tian, W. X., Xu, L. H., and Ibrahim, M. 2012. Characterization in and evaluation of Bacillus isolates for their potential plant growth and biocontrol activities against tomato bacterial wilt. Afr. J. Biotechnol. 11:7193-7201.

Aydi Ben Abdallah, R., Mokni-Tlili, S., Nefzi, A., Jabnoun-Khiareddine, H., and Daami-Remadi, M. 2016. Biocontrol of Fusarium wilt and growth promotion of tomato plants using endophytic bacteria isolated from Nicotiana glauca organs. Biol. Control 97:80-88.

Beneduzi, A., Peres, D., Vargas, L. K., Bodanese-Zanettini, M. H., and Passaglia, L. M. P. 2008. Evaluation of genetic diversity and plant growth promoting activities of nitrogen-fixing Bacilli isolated from rice fields in South Brazil. Appl. Soil Ecol. 39:311-320.

Bibi, F., Yasir, M., Song, G. C., Lee, S. Y., and Chung, Y. R. 2012. Diversity and characterization of endophytic bacteria associated with tidal flat plants and their antagonistic effects on Oomycetous plant pathogens. Plant Pathol. J. 28:20-31.

Chen, Y., Yan, F., Cai, Y. Y., Liu, H. X., and Guo, J. H. 2013. Biocontrol of tomato wilt disease by Bacillus subtilis isolates from natural environments depends on conserved genes mediating biofilm formation. Environ. Microbiol. 15:848-864.

Chernin, L., and Chet, L. 2002. Microbial enzymes in biocontrol of plant pathogens and pests. Pages 171-225 in: Enzymes in the Environment: Activity, Ecology, and Applications. R. G. Burns and R. P. Dick, eds. Marcel Dekker, Inc., New York, NY, U.S.A.

Chithrashree, Udayashankar, A. C., Chandra Nayaka, S., Reddy, M. S., and Srinivas, C. 2011. Plant growth-promoting rhizobacteria mediate induced systemic resistance in rice against bacterial leaf blight caused by Xanthomonas oryzae pv. oryzae. Biol. Control 59:114-122.

Chun, J., and Bae, K. S. 2000. Phylogenetic analysis of Bacillus subtilis and related taxa based on partial gyrA gene sequences. Antonie Leeuwenhoek 78:123-127.

Dean, R. A., Talbot, N. J., Ebbole, D. J., Farman, M. L., Mitchell, T. K., Orbach, M. J., Thon, M., Kulkarni, R., Xu, J. R., Pan, H., Read, N. D., Lee, Y. H., Carbone, I., Brown, D., Oh, Y. Y., Donofrio, N., Jeong, J. S., Soanes, D. M., Djonovic, S., and Birren, B. W. 2005. The genome sequence of the rice blast fungus Magnaporthe grisea. Nature 434:980-986.

Du, Y. X., Li, K., Ruan, H. C., Yang, X. J., Gan, L., and Chen, F. R. 2011. Sensitivities of Magnaporthe grisea to isoprothiolane, iprobenfos and tricyclazole. Acta Phytopathol. Sin. 38:455-460.

Fan, Q., Tian, S., Liu, H., and Xu, Y. 2002. Production of $\beta$-1,3-glucanase and chitinase of two bio-control agents and their possible modes of actin. Chin. Sci. Bull. 47:292-296.

Filippi, M. C. C., da Silva, G. B., Silva-Lobo, V. L., Cortes, M. V. V. B., and Prabhu, A. S. 2011. Leaf blast (Magnaporthe oryzae) suppression and growth promotion by rhizobacteria on aerobic rice in Brazil. Biol. Control 58:160-166.

Gao, T. T., Foulston, L., Chai, Y. R., Wang, Q., and Losick, R. 2015. Alternative modes of biofilm formation by plant-associated Bacillus cereus. MicrobiologyOpen 4:452-464.

Garrity, G. M., Bell, J. A., and Lilbum, T. G. 2004. Taxonomic outline of the prokaryotes. Pages 172-178 in: Bergey's Manual of Systematic Bacteriology, 2nd Ed. Springer-Verlag, New York, NY, U.S.A.

Goteti, P. K., Emmanuel, L. D., Desai, S., and Shaik, M. H. 2013. Prospective zinc solubilising bacteria for enhanced nutrient uptake and growth promotion in maize (Zea mays L.). Int. J. Microbiol. 2013: 869697.

Harish, S., Kavino, M., Kumar, N., Balasubramanian, P., and Samiyappan, R. 2009. Induction of defense-related proteins by mixtures of plant growth promoting endophytic bacteria against banana bunchy top virus. Biol. Control 51:16-25.

Hasanuzzaman, M., Bhuyan, M. H. M., Zulfiqar, F., Raza, A., Mohsin, S. M., Mahmud, J. A., Fujita, M., and Fotopoulos, V. 2020. Reactive oxygen species and antioxidant defense in plants under abiotic stress: Revisiting the crucial role of a universal defense regulator. Antioxidants 9:681.

Islam, S., Akanda, A. M., Prova, A., Islam, M. T., and Hossain, M. M. 2016. Isolation and identification of plant growth promoting rhizobacteria from cucumber rhizosphere and their effect on plant growth promotion and disease suppression. Front. Microbiol. 6:1360.

Jia, Y., Zhou, E., Lee, S., and Bianco, T. 2016. Co-evolutionary dynamics of rice blast resistance gene Pi-ta and Magnaporthe oryzae avirulence gene AVR-Pital. Phytopathology 106:676-683.

Jorquera, M., Martinez, O., Maruyama, F., Marschner, P., and de la Luz Mora, M. 2008. Current and future biotechnological applications of bacterial phytases and phytase-producing bacteria. Microbes Environ. 23:182-191.

Kravchenko, L. V., Makarova, N. M., Azarova, T. S., Provorov, N. A., and Tikhonovich, I. A. 2002. Isolation and phenotypic characteristics of growth-stimulating rhizobacteria (PGPR), with high root-colonizing and phytopathogenic fungi inhibiting abilities. Mikrobiologiia 71: 521-525.

Kumar, M. K. P., Amruta, N., Manjula, C. P., Puneeth, M. E., and Teli, K. 2017. Characterisation, screening and selection of Bacillus subtilis isolates for its biocontrol efficiency against major rice diseases. Biocontrol Sci. Technol. 27:1-19.

Kumar, S., Stecher, G., and Tamura, K. 2016. MEGA7: Molecular evolutionary genetics analysis version 7.0 for bigger datasets. Mol. Biol. Evol. 33:1870-1874.

Lan, B., Li, X. M., Huang, R. R., Hu, S. X., and Tu, G. Q. 2007. The resistance of different strains of rice blast (Magnaporthe grisea) in Jiangxi Province to isoprothiolane. Acta Agric. Univ. Jiangxiensis 29: 351-355.

Lin, F., Liu, N., Lai, D., Kang, X. H., Pang, N. W., Jiang, H. K., and Xu, H. H. 2017. A formulation of neem cake seeded with Bacillus sp. provides control over tomato Fusarium crown and root rot. Biocontrol Sci. Technol. 27:393-407. 
Lorck, H. 1948. Production of hydrocyanic acid by bacteria. Physiol. Plant. 1:142-146.

Mehta, S., and Nautiyal, C. S. 2001. An efficient method for qualitative screening of phosphate-solubilizing bacteria. Curr. Microbiol. 43:51-56.

Meng, X. K., Yu, J. J., Yu, M. N., Yin, X. L., and Liu, Y. F. 2015. Dry flowable formulations of antagonistic Bacillus subtilis strain T429 by spray drying to control rice blast disease. Biol. Control 85:46-51.

Miah, G., Rafii, M. Y., Ismail, M. R., Puteh, A. B., and Latif, M. A. 2012. Blast resistance in rice: A review of conventional breeding to molecular approaches. Mol. Biol. Rep. 40:2369-2388.

Mishra, S., and Behera, N. 2008. Amylase activity of a starch degrading bacteria isolated from soil receiving kitchen wastes. Afr. J. Biotechnol. 7:3326-3331.

Momose, A., Ohtake, N., Sueyoshi, K., Sato, T., and Ohyama, T. 2009. Nitrogen fixation and translocation in young sugarcane (Saccharum officinarum L.) plants associated with endophytic nitrogen-fixing bacteria. Microbes Environ. 24:224-230.

Montealegre, J. R., Reyes, R., Perez, L. M., Herrera, R., and Besoain, X. 2003. Selection of bioantagonistic bacteria to be used in biological control of Rhizoctonia solani in tomato. Electron. J. Biotechnol. 6:116127.

Muleta, D., Assefa, F., and Granhall, U. 2007. In vitro antagonism of rhizobacteria isolated from Coffea Arabica L. against emerging fungal coffee pathogens. Eng. Life Sci. 7:577-586.

Niu, B., Vater, J., Rueckert, C., Blom, J., and Borriss, R. 2013. Polymyxin P is the active principle in suppressing phytopathogenic Erwinia spp. by the biocontrol rhizobacterium Paenibacillus polymyxa M-1. BMC Microbiol. 13:137.

Ou, S. H. 1985. Rice Diseases, 2nd Ed. Commonwealth Agricultural Bureaux, Slough, U.K.

Prabavathy, V. R., Mathivanan, N., and Murugesan, K. 2006. Control of blast and sheath blight diseases of rice using antifungal metabolites produced by Streptomyces sp. PM5. Biol. Control 39:313-319.

Renwick, A., Campbell, R., and Coe, S. 1991. Assessment of in vivo screening systems for potential biocontrol agents of Gaeumannomyces graminis. Plant Pathol. 40:524-532.
Shan, H. Y., Zhao, M. M., Chen, D. X., Cheng, J. L., and An, D. R. 2013. Biocontrol of rice blast by the phenaminomethylacetic acid producer of Bacillus methylotrophicus strain BC79. Crop Prot. 44:29-37.

Shin, S. H., Lim, Y., Lee, S. E., Yang, N. W., and Rhee, J. H. 2001. CAS agar diffusion assay for the measurement of siderophores in biological fluids. J. Microbiol. Methods 44:89-95.

Thampi, A., and Bhai, R. S. 2017. Rhizosphere actinobacteria for combating Phytophthora capsici and Sclerotium rolfsii, the major soil borne pathogens of black pepper (Piper nigrum L.). Biol. Control 109:1-13.

Tiru, M., Muleta, D., Berecha, G., and Adugna, G. 2013. Antagonistic effects of rhizobacteria against coffee wilt disease caused by Gibberella xylarioides. Asian J. Plant Pathol. 7:109-122.

Todorova, S., and Kozhuharova, L. 2010. Characteristics and antimicrobial activity of Bacillus subtilis strains isolated from soil. World J. Microbiol. Biotechnol. 26:1207-1216.

Tokpah, D. P., Li, H. W., Wang, L. Y., Liu, X. Y., and Liu, H. X. 2016. An assessment system for screening effective bacteria as biological control agents against Magnaporthe grisea on rice. Biol. Control 103:21-29.

Wang, J. C., Correll, J., and Jia, Y. 2015. Characterization of rice blast resistance genes in rice Germplasm with monogeniclines and pathogenicity assays. Crop Prot. 72:132-138.

Wang, J. C., Jia, Y., Wen, J. W., Liu, W. P., Liu, X. M., Li, L., Jiang, Z. Y., Zhang, J. H., Guo, X. L., and Ren, J. P. 2013. Identification of rice blast resistance genes using international monogenic differentials. Crop Prot. 45:109-116.

Xi, Y. D., Liu, B. W., and Peng, H. X. 2009. Study on resistance of Pyricularia grisea to isoprothiolane in Sichuan Province. Southwest China J. Agric. Sci. 22:77-80.

Yu, Y. Y., Jiang, C. H., Wang, C., Chen, L. J., and Guo, J. H. 2017. An improved strategy for stable biocontrol agents selecting to control rice sheath blight caused by Rhizoctonia solani. Microbiol. Res. 203:1-9.

Yuan, J., Yang, X. H., He, H. Y., and Jin, X. 2005. Test on resistance of Magnaporthe grisea to isoprothiolane in Guizhou province. Acta Phytopathol. Sin. 35:71-73.

Zhang, X., Zhou, Y. Y., Li, Y., Fu, X. C., and Wang, Q. 2017. Screening and characterization of endophytic Bacillus for biocontrol of grapevine downy mildew. Crop Prot. 96:173-179. 